\title{
Analisis Persepsi Calon Guru Terhadap Pengembangan Keterampilan Probem Solving Melalui Pembelajaran Fisika
}

\author{
Erwin $^{1^{\star}}$, NY Rustaman ${ }^{2}$, H Firman ${ }^{3}$, TR Ramalis ${ }^{4}$ \\ 1,2,3 Program Studi Pendidikan IImu Pendidikan Alam, Sekolah Pascasarjana Universitas Pendidikan Indonesia, \\ JI. Dr.Setiabudi No. 229, Bandung 40154, Indonesia. \\ ${ }^{1}$ Sekolah Tinggi Keguruan dan IImu Pendidikan Nurul Huda, Kabupaten Ogan Komering Ulu Timur, Provinsi \\ Sumatera Selatan, Indonesia \\ ${ }^{4}$ Departemen Pendidikan Fisika, Fakultas Pendidikan Matematika dan Ilmu Pengetahuan Alam, Universitas \\ Pendidikan Indonesia, JI. Dr.Setiabudi No. 229, Bandung 40154, Indonesia. \\ "e-mail: erwinpohan74@student.upi.edu
}

\begin{abstract}
Abstrak
Artikel ini membahas tentang tanggapan mahasiswa calon guru terhadap pengembangan keterampilan problem solving melalui pembelajaran fisika. Pengumpulan data dilakukan menggunakan kuesioner dan wawancara untuk memperkuat data yang diperoleh melalui kuesioner, data dianalisis secara deskriptif. Hasil penelitian menunjukkan bahwa mahasiswa calon guru fisika baik yang sudah mengikuti Program Pengalaman Lapangan 2 (PPL 2) maupun yang sedang mengikuti PPL 1, secara umum berpendapat bahwa pengembangan keterampilan problem solving dapat dilakukan melalui pembelajaran materi subjek, khususnya pada pembelajaran fisika. Namun demikian ditemukan ada beberapa calon guru fisika memberikan tanggapan yang anomali untuk beberapa pernyataan pada angket, misalnya tidak menyetujui pernyataan yang berbunyi "Upaya memudahkan dalam menganalisis masalah guna penyelesaian masalah dilakukan dengan membuat gambar atau sketsa". Berdasarkan temuan ini perlu dicontohkan langkah-langkah yang perlu dibelajarkan dalam mengembangkan keterampilan problem solving, serta perlu diases kemampuannya dalam mengembangkan keterampilan problem solving yang terintegrasi pembelajaran fisika.
\end{abstract}

Kata kunci: calon guru fisika, problem solving, pembelajaran fisika.

\begin{abstract}
A study about development of problem solving skills in physics learning was conducted to investigate how prospective teachers were able to integrate this ability into physics instruction. This article discusses the responses of prospective teachers to the development of problem solving skills through physics learning. Data were collected by using questionnaires and interviews. To strengthen data obtained through questionnaires, data were analyzed descriptively. The results of the study show that prospective physics teachers who have participated in Field Experience Program 2 (PPL 2) or who are currently participating in PPL 1, in general, agree that problem solving skills can be developed through subject matter learning, especially in physics learning. However, there are some prospective physics teachers who gave anomalous responses to several statements in the questionnaire, for example there are students who do not approve the statement that reads "Facilitating and analyzing problems for problem solving is done by drawing or sketching". Based on these findings, it is necessary to provide a good understanding of the steps that should be taught in developing problem solving skills, such as giving example or modelling. Furthermore, prospective physics teachers need to be assessed their ability to teach the development of problem solving skills which was integrated with/in physics learning.
\end{abstract}

Keywords: prospective physics teacher, problem solving, physics learning.

\section{PENDAHULUAN}

Kurikulum Tahun 2013 yang direvisi
Tahun 2016 mengamanatkan pembelajaran materi subjek yang dilaksanakan harus diintegrasikan dengan pembelajaran keterampilan abad 21. Keterampilan abad 21 
yang diamanatkan untuk dibelajarkan kepada siswa sesuai dengan kurikulum 2013 tersebut dikenal dengan istilah $4 \mathrm{C}$ (critical thinking and problem solving skills, communication skills, creativity and innovation and collaboration) (Direktorat PSMA, 2017). Pentingnya membelajarkan keterampilan tersebut merupakan jawaban untuk menghadapi tantangan abad 21 yang semakin kompleks. Kenyataan dalam kehidupan sehari-hari menunjukkan memcahkan masalah merupakan hal yang dihadapi oleh banyak orang, sehingga keterampilan memecahkan masalah menjadi penting dimiliki oleh setiap orang. Ketika keterampilan problem solving terus berkembang, maka siswa akan lebih baik dalam menyelesaikan masalah yang dihadapinya, mengelola hidupnya dan menjadi individu yang lebih peraya diri.

Pembelajaran fisika merupakan salah satu pembelajaran yang potensial untuk mengembangkan kemampuan problem solving siswa (Warimun, 2012). Problem solving merupakan salah satu tujuan utama, alat pengajaran dan teknik evaluasi mata pelajaran fisika (Docktor \& Heller, 2009), begitu pentingnya problem solving dalam pembelajaran fisika, mendorong para ilmuan mengembangkan instrumen yang mengukur kemampuan problem solving siswa (Heller, Keith, \& Anderson, 1992; Foster, 2000; dan Docktor \& Heller, 2009).

Strategi problem solving pertama sekali digagas oleh Polya (1972), seorang matematikawan yang mengemukakan tahapan-tahapan problem solving yaitu: (1) Understanding the Problem (memahami masalah), (2) Devising a Plan (merencanakan solusi), (3) Carrying Out the Plan (melaksanakan rencana) dan (4) Looking Back (memeriksa kembali). IImuan fisika kemudian mengembangkan langkah-langkah problem solving dalam pembelajaran fisika yang diadaptasi dari langkah-langkah problem solving Polya. Langkah-langkah problem solving diperluas dari 4 langkah yang dikemukakan Polya (1972) menjadi 5 langkah yaitu: (1) Recognize the problem (memahami masalah), (2) Describe the problem in terms of the field (menggambarkan masalah dalam istilah fisika), (3) Plan a solution (merencanakan solusi), (4) Execute the plan (menggunakan solusi) dan (5) Evaluate the solution (mengevaluasi solusi) (Heller \& Heller, 2010).

Keterampilan pemecahan masalah dalam fisika dapat tidak lepas dari kemampuan siswa melakukan penggambaran masalah dalam istilah fisika (representasi masalah dalam bentuk bagan atau skema), langkah ini termasuk dalam langkah memahami masalah pada langkah pemecahan masalah yang dikemukakan Polya. Kesulitan dalam melakukan representasi akan menyebabkan kesulitan dalam menyelesaikan masalah fisika. Salah satu contoh representasi masalah dalam fisika adalah mengubah informasi kalimat menjadi diagram atau gambar seperti terdapat pada gambar 1.

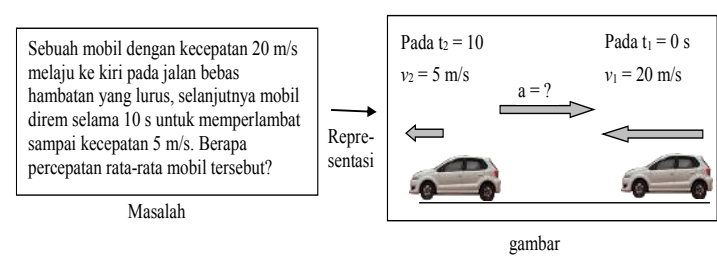

Gambar 1. Contoh representasi masalah untuk problem solving dalam fisika

Keterampilan problem solving merupakan salah satu keterampilan abad 21(Binkley et al., 2012; P21, 2011; Wagner, 2010; Lisbon Council, 2007). Pembelajaran keterampilan secara umum dilakukan secara terintegrasi dengan pembelajaran materi subjek (American Association of School Librarians, 2009; Saavedra \& Opfer, 2012; VIF International Education, 2014; dan Valli et al., 2014), dengan demikian guru harus memiliki kemampuan yang baik untuk membelajarkan keterampilan problem solving. Keterampilan merupakan salah satu pengetahuan konten yang harus dibelajarkan kepada siswa, pengetahuan konten meliputi, pengetahuan (i), pemahaman (ii), keterampilan (iii) dan disposisi (iv) (Shulman, 1987). Guru harus menguasai pengetahuan konten dimana keterampilan problem solving termasuk didalamnya dan ilmu mengajar (pedagogi), kemudian mengemas pengetahuan konten dengan pengetahuan pedagogi pada pengetahuan konten spesifik 
sehingga pengetahuan konten tersebut menjadi "teachable" dan "accessible" yang disebut Pedagogical Content Knowledge (PCK) oleh Shulman (1987). PCK harus dibekalkan kepada calon guru agar mereka menjadi guru yang profesional, sebuah penelitian pada suatu perguruan tinggi di Provinsi Sumatera Selatan, Indonesia menunjukkan masih rendahnya pemahaman calon guru fisika pada beberapa komponen PCK (erwin dan rustaman, 2017).

\section{METODE/EKSPERIMEN}

Penelitian ini dilakukan di salah satu Sekolah Tinggi Keguruan dan IImu Pendidikan (STKIP) di Provinsi Sumatera Selatan, melibatkan 36 orang responden, yaitu calon guru fisika yang telah selesai mengikuti praktek mengajar di sekolah (PPL 2) sebanyak 20 orang dan calon guru fisika yang sedang mengikuti perkuliahan untuk persiapan mengikuti praktek mengajar di sekolah (peer teaching dan micro teaching, PPL 1) sebanyak 16 orang. Calon guru fisika yang telah mengikuti PPL 2 telah selesai mengikuti program peer teaching dan micro teaching semester sebelumnya, PPL 2 dilaksanakan selama 2 (dua) bulan. Kemudian calon guru fisika telah mengikuti kegiatan PPL 1 diasumsikan sudah memiliki pemahaman yang cukup tentang praktek pembelajaran yang harus dilakukan oleh seorang calon guru. Responden diminta memberikan informasi mengenai bagaimana pemahaman mereka terhadap pentingnya pembelajaran keterampilan problem solving. Instrumen yang digunakan untuk pengumpulan data adalah angket.

Angket terdiri dari 10 item pernyataan tentang pembelajaran keterampilan problem solving yang terintegrasi dengan pembelajaran materi subjek fisika. Opsi pilihan yang disediakan pada angket terdiri dari sangat setuju, setuju, tidak setuju dan sangat tidak setuju. Penskoran menggunakan skala likert 4 poin. Skor 4 diberikan pada opsi sangat setuju untuk pernyataan positif dan sangat tidak setuju untuk pernyataan negatif. Skor 3 diberikan pada opsi setuju untuk pernyataan positif dan tidak setuju untuk pernyataan negatif. Skor 2 diberikan pada opsi tidak setuju untuk pernyataan positif dan setuju untuk pernyataan negatif. Serta Skor 1 diberikan pada opsi sangat tidak setuju untuk pernyataan positif dan sangat setuju untuk pernyataan negatif. Kisikisi dan angket terlampir.

Analisis data dilakukan secara deskriptif dengan memaparkan hasil temuan penelitian. Data yang berasal dari kuesioner dikuatifikasi dan dihitung rata-rata skor PCK calon guru serta disajikan dalam bentuk persentase.

\section{HASIL DAN PEMBAHASAN}

\section{Pandangan Calon guru fisika tentang Pengembangan Keterampilan problem solving melalui Pembelajaran Fisika}

Pandangan mahasiswa calon guru fisika tentang pembelajaran keterampilan problem solving diungkap melalui pemberian angket, angket yang disebarkan kepada mahsiswa kemudian dianalisis untuk mengungkap bagaimana pendapat mahasiswa calon guru membelajarkan keterampilan problem solving kepada siswa melalui pembelajaran fisika. Hasil penelitian menunjukkan bahwa secara umum mahasiswa calon guru berpendapat pembelajaran keterampilan problem solving penting dilakukan melalui pembelajaran materi fisika. Hal ini terlihat dari skor rata-rata tanggapan yang diberikan mahasiswa pada angket yang disebar berada pada angka 33,89 dari skor maksimum 40 atau berada pada persentasi skor $84,72 \%$.

Terdapat beberapa tangapan mahasiswa calon guru fisika terhadap pernyataan angket yang anomali antara lain: pernyatan nomor tiga yang berbunyi "Upaya memudahkan dalam menganalisis masalah guna penyelesaian masalah dilakukan dengan membuat gambar atau sketsa" ditanggapi 2 mahasiswa dengan memilih opsi tidak setuju, tanggapan kedua mahasiswa tersebut menunjukkan kekurang pahamannya tentang pentingnya keterampilan representasi informasi untuk menganalisis dan memudahkan pemahaman masalah sebagai salah satu langkah pemecahan masalah. Pernyataan keempat pada angket yang berbunyi "Upaya menyusun perecanaan penyelesaian masalah dalam pembelajaran fisika diawali dengan mencari hubungan antara 
data yang diketahui dengan apa yang belum diketahui", ditanggapi oleh 4 mahasiswa dengan memilih opsi sangat tidak setuju, hal ini memberikan informasi bahwa adanya kekeliruan pemahaman calon guru bahwa mencari hubungan antara apa yang diketahui dalam permasalahan dengan apa yang belum diketahui untuk memecahkan masalah bukanlah bagian dari menyusun rencana pemecahan, padahal menentukan langkah apa yang harus dilakukan dalam memecahkan masalah tentu harus dicari hubungan antara informasi yang sudah diketahui dalam permasalahan dengan yang apa yang belum diketahui. Pernyataan angket nomor lima yang berbunyi "Dalam pemecahan masalah pada pembelajaran fisika perlu dipahami teori atau persamaan yang akan digunakan", ditanggapi oleh 4 mahasiswa dengan memilih opsi tidak setuju, tanggapan ini mengisyaratkan kurangnya pengetahuan mahasiswa terhadap langkah-langkah pemecahan masalah yang utuh, memahami teori atau persamaan sangat dibutuhkan untuk memecahkan masalah fisika, secara umum siswa mengalami kesulitan memcahkan masalah fisika tanpa memahami teori atau persamaan yang relevan dengan masalah yang dihadapi. Selanjutnya, 1 orang mahasiswa calon guru memberikan tanggapan tidak setuju terhadap pernyataan nomor sembilan yang berbunyi "Solusi yang dibuat pada suatu masalah perlu dianalisis apakah memungkinkan untuk dilakukan pada masalahmasalah yang sama". Tanggapan mahasiswa ini menunjukkan bahwa pemahamannya terhadap kemungkinan diterapkannya langkahlangah penyelesaian masalah pada suatu masalah tertentu tidak perlu dianalisis untuk penerapannya pada masalah lain yang mungkin memiliki karakteristik yang sama. Padahal banyak langkah-langkah pemecahan masalah yang dapat diterapkan pada masalahmasalah serupa dalam memecahkannya. Perbandingan jumlah mahasiswa yang memilih opsi sangat setuju/setuju dengan tidak setuju/sangat tidak setuju terhadap setiap pernyataan angket secara lengkap ditunjukkan pada gambar 2 .

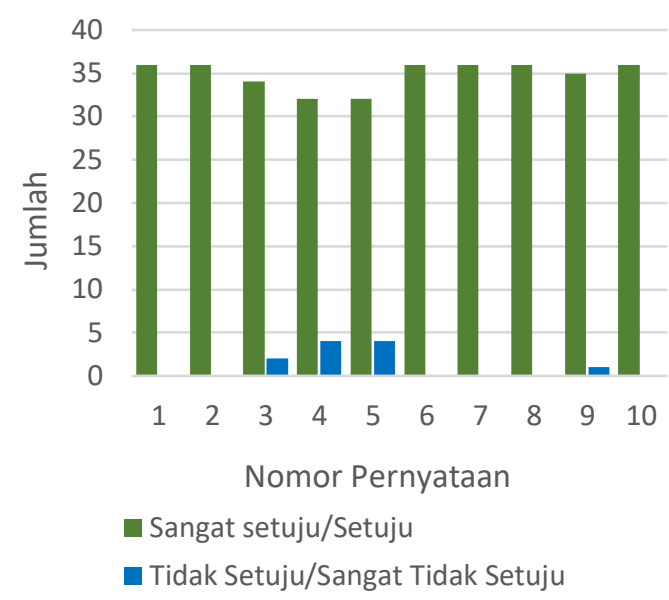

Gambar 2. Grafik perbandingan jumlah yang memilih opsi sangat setuju/setuju dengan tidak setuju/sangat tidak setuju

Tanggapan calon guru fisika terhadap beberapa pernyataan lain yang perlu ditindaklanjuti melalui pemberian penekanan, dalam pengembangan keterampilan problem solving siswa adalah tanggapan calon guru fisika terhadap pernyataan yang menunjukkan adanya keraguan dalam memberikan tanggapan, misalnya tanggapan terhadap pernyataan nomor dua yang berbunyi "Salah satu langkah untuk menyelesaikan masalah pada pembelajaran fisika adalah dengan memahami apa yang menjadi fokus permasalahan" sebanyak 20 calon guru fisika sangat setuju dengan pernyataan ini, namun terdapat 16 calon guru fisika yang menyatakan hanya setuju, pernyataan setuju menunjukkan adanya keraguan bahwa salah satu langkah dalam pemecahan masalah adalah memahami fokus masalah, jika calon guru fisika tidak memiliki keraguan bahwa salah satu langkah pemecahan masalah dengan memahami fokus masalah maka calon guru fisika tanpa ragu akan memilih opsi sangat setuju.

Penyataan angket nomor 3, 4, 5, 6, 9 dan 10 juga ditanggapi oleh sebagian besar calon guru fisika dengan memilih opsi setuju, hal ini menunjukkan adanya keraguan keyakinan calon guru fisika pada pernyataan tersebut sehingga lebih sedikit yang memilih opsi sangat setuju. Bahkan jumlah yang memilih opsi setuju lebih $50 \%$. 


\section{Perbandingan Pandangan Calon guru antara yang telah mengikuti PPL 2 dan yang sedang mengikuti PPL 1 tentang pengembangan Keterampilan problem solving pada pembelajaran fisika.}

Berdasarkan data yang diperoleh dari penyebaran angket terhadap calon guru fisika yang telah selesai mengikuti PPL 2 dan yang sedang mengikuti PPL 1 diperoleh gambaran bahwa kedua kelompok calon guru fisika tersebut secara rata-rata memberikan tanggapan yang sama terhadap angket tentang pembelajaran keterampilan problem solving melalui pembelajaran fisika. Hal ini menunjukkan bahwa kedua kelompok calon guru fisika tersebut memiliki pandangan yang sama bahwa pengembangan keterampilan problem solving sangat dimungkinkan untuk dilakukan pada pembelajaran fisika.

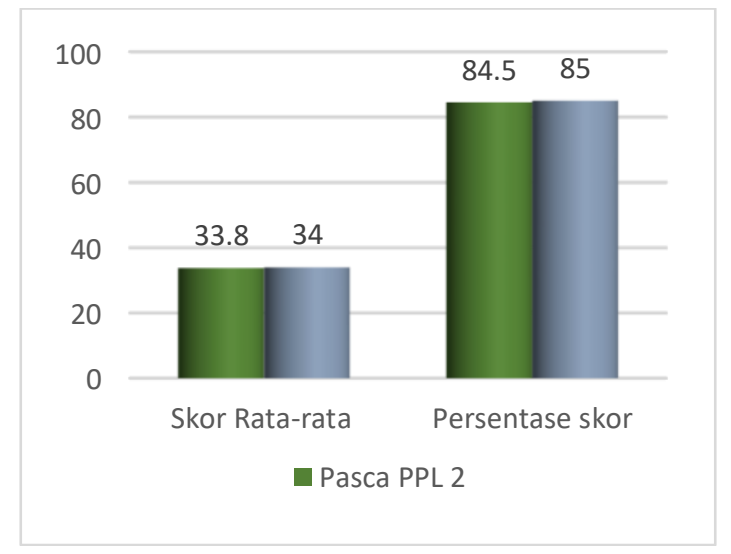

Gambar 3. Grafik skor rata-rata dan persentase skor tanggapan calon guru terhadap pembelajaran keterampilan Problem solving melalui pembelajaran fisika

Perbandingan skor dan persentase skor tanggapan calon guru fisika calon guru yang telah mengikuti PPL 2 dengan yang sedang mengikuti PPL 1 terhadap pengembangan keterampilan problem solving melalui pembelajaran fisika terlihat pada gambar 3 . Rata-rata skor yang diperoleh kelompok calon guru fisika calon guru yang telah mengikuti PPL2 adalah 33,8 atau 84,5\% sedangkan ratarata skor calon guru fisika yang sedang mengikuti PPL 1 sebesar 34,0 atau 85,0 \%. Meskipun secara rata-rata skor tanggapan kedua kelompok calon guru fisika tidak menunjukkan perbedaan, namun beberapa pernyataan pada angket ditanggapi berbeda oleh kedua kelompok, khususnya pada pernyataan-pernyataan yang ditanggapi secara anomali.

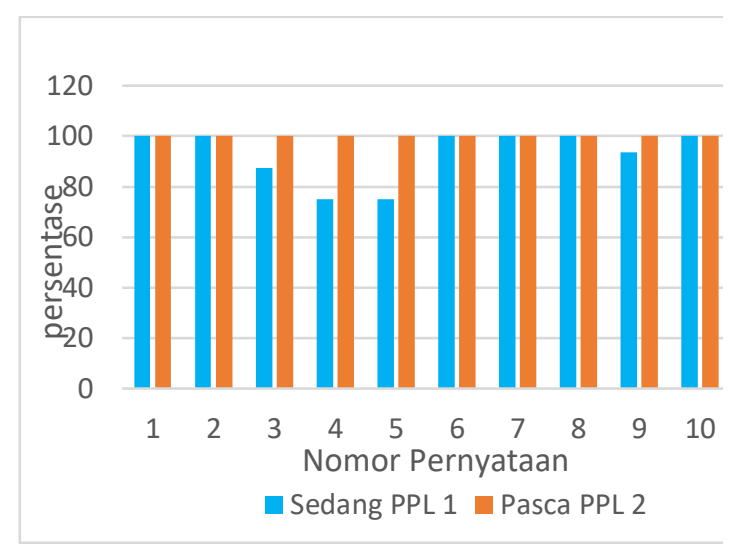

Gambar 4. Grafik persentase calon guru fisika yang sangat setuju/setuju terhadap pernyataan dalam angket

Gambar 4 menunjukkan bahwa hanya calon guru fisika yang sedang PPL 1 yang memberi tanggapan anomali terhadap angket, sedangkan semua calon guru fisika yang telah selesai PPL 2 menyatakan setuju/sangat setuju terhadap semua pernyataan dalam angket. Wawancara dilakukan dengan calon guru fisika yang sedang PPL 1 untuk mengklarifikasi respon mereka yang anomali terhadap pernyataan angket. Hasil wawancara menunjukkan kurang pahamnya calon guru fisika mengenai langkah-langkah problem solving, sebagian calon guru fisika menyatakan belum pernah mempelajari langkah-langkah problem solving, bahkan sebagian besar belum mengetahui bahwa keterampilan problem solving merupakan salah satu keterampilan abad 21 yang harus dibelajarkan kepada siswa sesuai dengan kurikulum 2013 yang telah direvisi tahun 2016. Dengan demikian perlu dilakukan perkuliahan yang menekankan pentingnya membelajarkan problem solving pada siswa, pembelajaran problem solving dilakukan terintegrasi dengan pembelajaran materi subjek. 
Erwin, NY Rustaman, H Firman, TR Ramalis

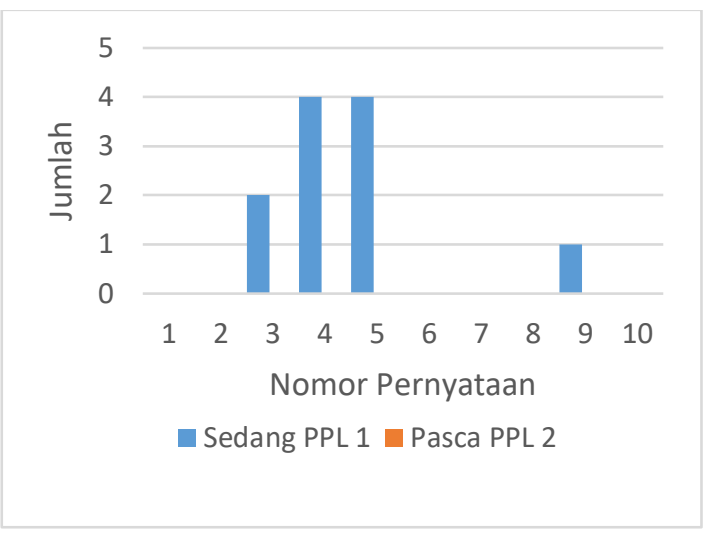

Gambar 5. Grafik jumlah calon guru fisika yang tidak setuju/sangat tidak setuju terhadap pernyataan dalam angket

Jumlah calon guru fisika yang memberikan tanggapan yang anomali dan pernyataan angket mana saja yang ditanggapi anomali terlihat pada gambar 5. Pernyataan nomor 3 ditanggapi secara anomali oleh 2 calon guru fisika, pernyataan nomor 4 ditanggapi secara anomali oleh 4 calon guru fisika, pernyataan nomor 5 juga ditanggapi secara anomali oleh 4 calon guru fisika dan pernyataan nomor 9 ditanggapi secara anomali oleh 1 calon guru fisika.

Bertitiktolak dari temuan penelitian, selain memberikan bekal kemampuan membelajarkan keterampilan problem solving kepada calon guru fisika calon guru melalui latihan penerapan langkah-langkah problem solving melalui pembelajaran fisika, perlu dilakukan asesmen untuk memastikan apakah calon guru fisika telah kemampuan memiliki kemampuan yang memadai dalam mengembangkan keterampilan problem solving siswa melalui pembelajaran fisika pada saat calon guru fisika sedang mengikuti PPL 1 dan PPL 2.

\section{PENUTUP}

Tanggapan calon guru fisika yang menjadi subjek penelitian secara umum menyetujui bahwa pengembangan keterampilan problem solving dilakukan secara terntegrasi dengan pembelajaran materi subjek, hal ini terlihat dari skor rata-rata tanggapan mahasiswa pada angket berada pada persentasi skor $84,72 \%$. Secara khusus keterampilan problem solving dapat dikembangkan melalui pembelajaran fisika. Beberapa tanggapan calon guru fisika terhadap pernyataan angket yang anomali menunjukkan masih kurangnya pemahaman calon guru fisika terhadap langkah-langkah problem solving, sehingga perlu dilakukan asesmen PCK calon guru dalam mengembangkan keterampilan problem solving siswa. Untuk peningkatan pemahaman mahasiswa tentang pembelajaran keterampilan problem solving, perlu dilakukan penekanan khusus dalam perkuliahan bagaimana strategi yang potensial membelajarkan pengembangan ketarampilan tersebut.

\section{UCAPAN TERIMA KASIH}

Terima kasih yang tak terhingga penulis ucapkan kepada Bapak Kholid Mawardi, M.Si. Bupati OKU Timur yang telah memberikan bantuan biaya untuk penelitian ini dan Bapak Effendi, M.Pd, dosen program studi pendidikan fisika STKIP Nurul Huda Sukaraja, Kabupaten OKU Timur, Provinsi Sumatera Selatan yang telah banyak membantu dalam pengumpulan data penelitian.

\section{DAFTAR PUSTAKA}

American Association of School Librarians. (2009). Standards for the 21st- Century Learner in Action. Chicago: American Association of school librarians.

Binkley, M., Erstad, O., Herman, J., Raizen, S., Ripley, M., Miller-Ricci, M., \& Rumble, M. (2012). Defining Twenty-First Century Skills (in Griffin P, Barry McGaw \& Esther Care. 2012. Assessment and Teaching of 21st Century Skills. Springer: Dordrecht. https://doi.org/10.1007/978-94-007-2324-5 2

Direktorat PSMA Ditjen. Pendidikan Dasar dan Menengah. 2017. Implementasi Pengembangan Kecakapan Abad 21 dalam Perencanaan Pelaksanaan Pembelajaran $(R P P)$. Jakarta: Direktorat Pembinaan SMA Ditjen Dikdasmen.

Docktor, J., \& Heller, K. (2009). Robust Assessment Instrument For Student Problem Solving. Proceedings of the NARST. Annual Meeting. 
http://groups.physics.umn.edu/physed/Talks/ Docktor NARST09 paper.pdf

Erwin, E and Rustaman, N. Y. (2017). Understanding of Prospective Physics Teachers Students Toward Pedagogical Content Knowledge on Optical Geometry Materials. Journal of Physics: Conference Series, $\quad 895, \quad 012102$. https://doi.org/10.1088/1742$\underline{6596 / 895 / 1 / 012102}$

Foster, T. (2000). The development of students' problem-solving skills from instruction emphasizing qualitative problem-solving. (Unpublished doctoral dissertation, University of Minnesota, Twin Cities.)

Heller, K \& P. Heller. (2010). Cooperative Problem Solving in Physics A User's Manual. [Online]. Tersedia:

http://www.aapt.org/Conferences/newfaculty/ upload/Coop-Problem-Solving-Guide.pdf

Heller, P., Keith, R., \& Anderson, S. (1992). Teaching problem solving through cooperative grouping. Part 1: Group versus individual problem solving. American Journal of Physics, 600(7), 627-636. https://doi.org/10.1119/1.17117

Lisbon Council. (2007). Skills for the future (Brussels: Lisbon Council). Available online at: www.lisboncouncil.net/component/download s/?id=214 (accessed 11 February 2018).

P21. 2011. Framework for 21st Century Learning. Washington DC, Partnership for 21st Century
Skills.

Polya, G. (1957). How to solve it: A new aspect of mathematical method. Princeton, NJ: Princeton University Press.

Saavedra, A., \& Opfer, V. 2012. Teaching and Learning 21st Century Skills: Lessons from the Learning Sciences. A Global Cities Education Network Report. New York, Asia Society.

Shulman, L. S. (1987). Knowledge and Teaching: Foundations of the New Reform. Harvard Educational Review, 57, 1-22.

Valli, B. P., Perkkilä, P., \& Valli, R. (2014). Adult PreService Teachers Applying 21st Century Skills in the Practice. Athens Journal of Education, 2(1), 115-129.

VIF International Education. (2014). Global-Ready Teacher Competency Framework: Standart and Indicators. Tersedia: http://learn.vifprogram .com/rs/vifinternationaleducation/images/ Teacher Standards and Indicators.pdf. diakses 20 Mei 2017.

Wagner, T. (2010). Overcoming The Global Achievement Gap (online). Cambridge, Mass., Harvard University.

Warimun, E. S. (2012). Penerapan Model Pembelajaran Problem Solving Fisika pada Pembelajaran Topik Optika pada Calon guru fisika Pendidikan Fisika. Jurnal Exacta, 10(2), 111-114. 
Lampiran 1

Kisi-kisi instrumen tanggapan calon guru fisika terhadap pembelajaran keterampilan problem solving

\begin{tabular}{|c|c|c|c|}
\hline No & Langkah & Indikator & $\begin{array}{l}\text { No } \\
\text { Item }\end{array}$ \\
\hline 1 & $\begin{array}{l}\text { Memahami } \\
\text { masalah }\end{array}$ & $\begin{array}{l}\text { 1. Mampu menjelaskan data apa yang diketahui } \\
\text { 2. Mampu menjelaskan apa yang ditanya } \\
\text { 3. Mampu membuat gambar atau skema }\end{array}$ & $\begin{array}{l}1 \\
2 \\
3\end{array}$ \\
\hline 2 & $\begin{array}{l}\text { Menyusun } \\
\text { rencana } \\
\text { pemecahan }\end{array}$ & $\begin{array}{l}\text { 1. Menemukan hubungan antara data dengan hal-hal } \\
\text { yang belum diketahui } \\
\text { 2. Menentukan teori atau persamaan yang akan } \\
\text { digunakan }\end{array}$ & 4 \\
\hline 3 & $\begin{array}{l}\text { Melaksanakan } \\
\text { rencana }\end{array}$ & $\begin{array}{l}\text { 1. Melakukan dan memeriksa setiap langkah apakah } \\
\text { sudah benar } \\
2 \text { Membuktikan bahwa perhitungan, langkah-langkah } \\
\text { dan prosedur sudah benar }\end{array}$ & $\begin{array}{l}6 \\
7\end{array}$ \\
\hline 4 & $\begin{array}{l}\text { Memeriksa } \\
\text { kembali }\end{array}$ & $\begin{array}{l}\text { 1. Melakukan pemeriksaan kembali terhadap proses } \\
\text { dan solusi yang dibuat untuk untuk memastikan } \\
\text { bahwa cara itu sudah baik dan benar. }\end{array}$ & $\begin{array}{l}9 \\
10\end{array}$ \\
\hline
\end{tabular}


Lampiran 2

\section{ANGKET TANGGAPAN MAHASISWA CALON GURU FISIKA TENTANG PEMBELAJARAN KETERAMPILAN PROBLEM SOLVING}

Nama

NIM

Jenis kelamin

Semester

Petunjuk

Berikanlah tanda cek $(\sqrt{ })$ pada kolom yang sesuai dengan posisi anda terhadap pernyataan yang diberikan.

\begin{tabular}{|c|c|c|c|c|c|}
\hline & Pernyataan & $\begin{array}{l}\text { Sangat } \\
\text { setuju }\end{array}$ & Setuju & $\begin{array}{l}\text { Tidak } \\
\text { setuju }\end{array}$ & $\begin{array}{l}\text { Sangat } \\
\text { tidak } \\
\text { setuju }\end{array}$ \\
\hline 1. & $\begin{array}{l}\text { Untuk menyelesaikan suatu masalah atau soal pada } \\
\text { pembelajaran fisika perlu diawali dengan melakukan identifikasi } \\
\text { terhadap data apa saja yang diketahui. }\end{array}$ & & & & \\
\hline 2. & $\begin{array}{l}\text { Salah satu langkah untuk menyelesaikan masalah pada } \\
\text { pembelajaran fisika adalah dengan memahami apa yang } \\
\text { menjadi fokus permasalahan. }\end{array}$ & & & & \\
\hline 3. & $\begin{array}{l}\text { Upaya memudahkan dalam menganalisis masalah guna } \\
\text { penyelesaian masalah dilakukan dengan membuat gambar atau } \\
\text { sketsa. }\end{array}$ & & & & \\
\hline 4. & $\begin{array}{l}\text { Upaya menyusun perecanaan penyelesaian masalah dalam } \\
\text { pembelajaran fisika diawali dengan mencari hubungan antara } \\
\text { data yang diketahui dengan apa yang belum diketahui. }\end{array}$ & & & & \\
\hline 5. & $\begin{array}{l}\text { Dalam pemecahan masalah pada pembelajaran fisika perlu } \\
\text { dipahami teori atau persamaan yang akan digunakan. }\end{array}$ & & & & \\
\hline 6. & $\begin{array}{l}\text { Dalam pemecahan masalah pada pembelajaran fisika perlu } \\
\text { dilakukan pemeriksaan terhadap langkah-langkah yang telah } \\
\text { dilakukan apakah sudah benar atau belum. }\end{array}$ & & & & \\
\hline 7. & $\begin{array}{l}\text { Untuk memastikan bahwa pemecahan masalah yang dilakukan } \\
\text { sudah benar atau belum perlu dilakukan pembuktian kembali }\end{array}$ & & & & \\
\hline 8. & $\begin{array}{l}\text { Agar tidak keliru dalam langkah dan proses pemecahan } \\
\text { masalah, maka perlu diperiksa kembali proses dan solusi yang } \\
\text { dibuat. }\end{array}$ & & & & \\
\hline 9. & $\begin{array}{l}\text { Solusi yang dibuat pada suatu masalah perlu dianalisis apakah } \\
\text { memungkinkan untuk diterapkan pada masalah-masalah yang } \\
\text { sama. }\end{array}$ & & & & \\
\hline 10. & $\begin{array}{l}\text { Disamping solusi yang telah dilakukan pada suatu masalah, } \\
\text { perlu dicari dan dilakukan telaah mencari solusi lain untuk } \\
\text { memecahkan masalah tersebut. }\end{array}$ & & & & \\
\hline
\end{tabular}

